\title{
Effects of dietary clinoptilolite and calcium levels on uric acid and calcium blood concentrations and bone quality of commercial layers
}

\section{mAuthor(s)}

Berto DA ${ }^{1 *}$

Garcia EA ${ }^{2}$

Vercese $\mathrm{F}^{1}$

Santos GC dos

Barreiro FR

Molino A de B

Pelícia $\mathrm{K}^{3}$

Silveira AF $d a^{5}$

Students of the Post-Graduation Program in Animal Science, FMVZ, UNESP-Botucatu, Brazil

2 Assistant Prof. of the Department of Animal Production, FMVZ, Unesp-Botucatu, Brazil.

3 Professor of the Department of Animal Science, UNIFENAS, Alfenas/MG, Brazil

4 Student of the Post-Graduation Program in Veterinary Medicine, UNESP-Jaboticabal, Brazil

Undergraduate students of Animal Science, FMVZ, UNESP-Botucatu, Brazil

Project funded by Fundação de Amparo à Pesquisa do Estado de São Paulo.

** Grantee of Coordenação de Aperfeiçoamento de Pessoal de Nível Superior

\section{-Mail Adress}

Corresponding author e-mail address Universidade Estadual Paulista Júlio de Mesquita Filho - UNESP

Faculdade de Medicina Veterinária e Zootecnia - Departamento de Melhoramento e Nutrição Animal FAZENDA LAGEADO.

Distrito de Rubião Júnior, s/n - 18618-970 Botucatu/SP - Brasil

E-mail: daniellaberto23@yahoo.com.br

\section{nKeywords}

Mineral homeostasis, bone quality, zeolite.

\section{ABSTRACT}

The objective of the present study was to evaluate the effect of clinoptilolite and calcium levels on uric acid and calcium blood profile and bone quality of commercial layers. A total of 576 birds were distributed according to a completely randomized experimental design in a $3 \times 4$ factorial arrangement (calcium levels of $2.5,3.1$, or $3.7 \%$ and clinoptilolite levels of $0.0,0.15,0.25$, or $0.50 \%$ ), into 12 treatments with six replicates of eight birds per cage (experimental unit). The experimental period was 112 days. The experimental diets were based on corn and soybean meal. Results were submitted to analysis of variance and means were compared by the test of Tukey at $5 \%$ significance level using SISVAR statistical package. Blood uric acid was significantly influenced by the interaction of the evaluated factors. Clinoptilolite levels significantly increased blood calcium levels. There was no effect of dietary calcium levels on any of the evaluated characteristics. It was concluded that feeding layers with up to $0.50 \%$ clinoptilolite does not benefit blood uric acid and calcium concentrations and does not affect their bone quality. When layers at the end of the first laying cycle are fed ad libitum and present $119.50 \mathrm{~g} / \mathrm{hen} /$ day average feed intake, $3.1 \%$ dietary calcium promotes $3.7 \mathrm{~g} / \mathrm{hen} /$ day calcium intake, which is sufficient to maintain adequate calcium blood levels and bone quality.

\section{INTRODUCTION}

Optimizing poultry performance requires applying adequate management and health practices, as well as having efficient genetic improvement and nutrition programs. Relative to nutrition, there are many nutrients that have been extensively studied, such as calcium, which is the most prevalent mineral in the body of poultry and makes up approximately $1.5 \%$ of its weight (Underwood, 1981; Larbier \& Leclerq, 1992; Highfill, 1998), and one third of the total mineral content of a mature bird (Klasing, 1998).

Calcium studies usually focus on limestone dietary levels, sources, particle size, and solubility (Bronner, 1987; Albano Júnior et al., 2000; Pelícia, 2008), interactions with other minerals (Keshavarz, 1986; Junqueira \& Rodrigues, 2004), and the use of additives that improve calcium absorption and utilization (Roland et al., 1985; Rabon et al., 1991; Frost et al., 1992).

Among the additives that may improve calcium absorption, zeolites are highlighted. Zeolites are alkaline or alkaline-earth hydrated aluminosilicates (Luz, 1995). The most abundant natural zeolite is clinoptilolite (Santúrio et al., 1999; Armbruster, 2001), which structure provides it with specific characteristics, such as high cation exchange capacity, and the capacity to absorb substances that are harmful to the body (Mumpton, 1999). 
Ammonia is a harmful substance absorbed by clinoptilolite (Shurson et al., 1984). High ammonia levels in the intestine are toxic (Zigger, 1998), causing, for instance, changes in calcium absorption due to the possible reduction of vitamin $D$ activation in the liver and in the kidneys. Such organs have regulatory mechanisms to try to eliminate toxic substances from the body (Macari et al., 2002) and these may be overwhelmed by high ammonia levels. One of the consequences of impaired calcium absorption is poor bone quality. Calcium and phosphorus are essential for bone tissue synthesis, and the balance between the deposition and the mobilization of these minerals may increase or reduce bone mass (Pizauro Jr., 2002).

Therefore, this study aimed at evaluating the effects of different dietary clinoptilolite and calcium levels on blood uric acid and calcium contents and on the bone quality of commercial layers.

\section{MATERIALS AND METHODS}

In total, 576 Hisex Brown® layers, 67-week-old in the beginning of the experiment, were housed in laying cages. Birds were distributed according to a completely randomized experimental design with a $3 \times 4$ factorial arrangement (three calcium levels $x$ four clinoptilolite levels) into 12 treatments with six replicates of eight birds each. Calcium was added to the diet at 2.5, 3.1, or $3.7 \%$ and clinoptilolite at $0.0,0.15,0.25$, or $0.50 \%$.

The experimental period was 112 days. The lighting program adopted was 17 hours of light daily. Birds were offered feed and water ad libitum during the entire experimental period. The experimental diets were based on corn and soybean meal and were formulated according to feedstuff compositions and nutritional requirements of semi-heavy layers in lay recommended by Rostagno et al. (2005), except for calcium levels (Table 1).

At the end of the experimental period, uric acid and calcium blood levels were determined. Bone quality was assessed by bone mineral density, breaking strength, and ash percentage in the tibia.

In order to determine uric acid and calcium blood concentrations, $3 \mathrm{~mL}$ of blood were collected from six birds per treatment by brachial vein puncture using $5 \mathrm{~mL}$ syringes and $0.55 \times 20 \mathrm{~mm}$ needles. Blood was always collected in the morning, immediately before lay, aiming at minimizing possible interferences on blood

Table 1 - Ingredients and calculated nutritional composition of the experimental diets.

\begin{tabular}{|c|c|c|c|c|c|c|c|c|c|c|c|c|}
\hline \multirow[b]{2}{*}{ Ingredients } & \multicolumn{12}{|c|}{ Treatments } \\
\hline & 1 & 2 & 3 & 4 & 5 & 6 & 7 & 8 & 9 & 10 & 11 & 12 \\
\hline Corn & 56.34 & 58.38 & 60.43 & 56.52 & 58.57 & 60.61 & 56.65 & 58.69 & 60.74 & 56.95 & 58.99 & 61.04 \\
\hline Soybean meal & 15.21 & 16.52 & 17.84 & 15.33 & 16.65 & 17.96 & 15.41 & 16.72 & 18.04 & 15.60 & 16.92 & 18.24 \\
\hline Wheat & 20.83 & 15.90 & 10.96 & 20.39 & 15.46 & 10.52 & 20.09 & 15.16 & 10.23 & 19.36 & 14.42 & 9.49 \\
\hline Limestone* & 5.66 & 7.19 & 8.72 & 5.65 & 7.17 & 8.70 & 5.64 & 7.17 & 8.69 & 5.62 & 7.15 & 8.67 \\
\hline Dicalcium phosphate & 1.00 & 1.07 & 1.13 & 1.01 & 1.07 & 1.14 & 1.01 & 1.08 & 1.14 & 1.02 & 1.09 & 1.15 \\
\hline Methionine & 0.15 & 0.14 & 0.14 & 0.14 & 0.14 & 0.14 & 0.14 & 0.14 & 0.14 & 0.14 & 0.14 & 0.14 \\
\hline Lysine & 0.16 & 0.15 & 0.13 & 0.16 & 0.14 & 0.13 & 0.16 & 0.14 & 0.12 & 0.16 & 0.14 & 0.12 \\
\hline Salt & 0.35 & 0.35 & 0.35 & 0.35 & 0.35 & 0.35 & 0.35 & 0.35 & 0.35 & 0.35 & 0.35 & 0.35 \\
\hline Mineral supplement ${ }^{1}$ & 0.10 & 0.10 & 0.10 & 0.10 & 0.10 & 0.10 & 0.10 & 0.10 & 0.10 & 0.10 & 0.10 & 0.10 \\
\hline Vitamin supplement $^{2}$ & 0.10 & 0.10 & 0.10 & 0.10 & 0.10 & 0.10 & 0.10 & 0.10 & 0.10 & 0.10 & 0.10 & 0.10 \\
\hline Mycotoxin adsorbent & 0.10 & 0.10 & 0.10 & 0.10 & 0.10 & 0.10 & 0.10 & 0.10 & 0.10 & 0.10 & 0.10 & 0.10 \\
\hline Clinoptilolite & 0.00 & 0.00 & 0.00 & 0.15 & 0.15 & 0.15 & 0.25 & 0.25 & 0.25 & 0.50 & 0.50 & 0.50 \\
\hline Total & 100.00 & 100.00 & 100.00 & 100.00 & 100.00 & 100.00 & 100.00 & 100.00 & 100.00 & 100.00 & 100.00 & 100.00 \\
\hline \multicolumn{13}{|c|}{ Calculated nutritional composition } \\
\hline $\begin{array}{l}\text { Metabolizable energy } \\
\text { (kcal/kg) }\end{array}$ & 2800 & 2800 & 2800 & 2800 & 2800 & 2800 & 2800 & 2800 & 2800 & 2800 & 2800 & 2800 \\
\hline Crude protein (\%) & 14.78 & 14.78 & 14.78 & 14.78 & 14.78 & 14.78 & 14.78 & 14.78 & 14.78 & 14.78 & 14.78 & 14.78 \\
\hline Calcium (\%) & 2.50 & 3.10 & 3.70 & 2.50 & 3.10 & 3.70 & 2.50 & 3.10 & 3.70 & 2.50 & 3.10 & 3.70 \\
\hline $\begin{array}{l}\text { Available phosphorus } \\
(\%)\end{array}$ & 0.33 & 0.33 & 0.33 & 0.33 & 0.33 & 0.33 & 0.33 & 0.33 & 0.33 & 0.33 & 0.33 & 0.33 \\
\hline Total methionine (\%) & 0.36 & 0.36 & 0.36 & 0.36 & 0.36 & 0.36 & 0.36 & 0.36 & 0.36 & 0.36 & 0.36 & 0.36 \\
\hline $\begin{array}{l}\text { Total methionine + } \\
\text { cystine }(\%)\end{array}$ & 0.66 & 0.66 & 0.66 & 0.66 & 0.66 & 0.66 & 0.66 & 0.66 & 0.66 & 0.66 & 0.66 & 0.66 \\
\hline Total lysine (\%) & 0.73 & 0.73 & 0.73 & 0.73 & 0.73 & 0.73 & 0.73 & 0.73 & 0.73 & 0.73 & 0.73 & 0.73 \\
\hline
\end{tabular}

${ }^{1}$ Mineral levels per kg of feed: Cu: 8 mg; Fe:50 mg; Mn: 70 mg; Zn:50 mg; I: 1.2 mg; Se: 0.2 mg. ${ }^{2}$ Vitamin levels per kg of feed: Vit. A: 7000 IU; vit. D3: 2000 IU;

vit. E: 5 mg; vit. K3: 1.6 mg; vit. B2: 3mg; vit. B12: 8 mcg; Niacin: 20 mg; pantothenic acid: 5 mg; antioxidant: 15 mg. ${ }^{*}$ Calcitic limestone $100 \%$ fine. 
calcium levels. The collected blood was immediately transferred from the syringe to vacutainer $®$ (BD) tubes containing sodium heparin as anti-clotting agent. Tubes were centrifuged at 5000rpm for $10 \mathrm{~min}$ to separate the plasma. Uric acid and calcium blood concentrations were determined according to the methodology proposed by Perkin-Eimer Corporation (1996).

Six birds per treatment (one per replicate) were sacrificed to collect the left tibia for bone quality assessment. Mineral density was determined by optical densitometry of bone radiographs, and expressed in millimeters of aluminum ( $\mathrm{mm} \mathrm{Al}$ ), according to Louzada (1994).

After bone mineral density determination, bone breaking strength was analyzed. A specific cell, coupled to a texture analyzer (Texture Analyser TA. XT Plus) with the use of a probe (Blade Set HDP/BS) at $2 \mathrm{~mm} / \mathrm{s}$ pre-test speed, $1.0 \mathrm{~mm} / \mathrm{s}$ test speed, and $40 \mathrm{~mm} / \mathrm{s}$ posttest speed, was used. Tibiae were placed at the central position with $6 \mathrm{~cm}$ clearance, allowing the comparison of breaking strength values. A software program recorded the strength required for complete bone breaking and values were expressed in kilograms-force (kgf).

After breaking strength evaluation, bone ash content was determined according to the methodology proposed by Nogueira \& Souza (2005).

Results were statistically analyzed using SISVAR statistical package, according to Ferreira (1998). The obtained data were submitted to analysis of variance and means were compared by the test of Tukey at 5\% significance level. Regression analyses were used when applicable.

\section{RESULTS AND DISCUSSION}

Blood uric acid level was affected by the interaction between clinoptilolite and calcium levels (Tables 2 and 3).

Feed intake was not influenced ( $p>0.05$ ) by dietary clinoptilolite or calcium levels. Reviewing the literature, there are different and consistent results relative to our findings (Nakaue \& Koelliker, 1981; Roland, 1988; Roland et al., 1991; Frost et al., 1992; Shariatmadari, 2008; Pelícia et al., 2011). The contradictory literature reports may be due to the use of different layer genetic strains as well as different zeolite and calcium levels and sources applied in the diets.

Clinoptilolite levels influenced $(p \leq 0.05)$ calcium blood concentration. The highest concentrations were obtained in birds fed $0.25 \%$ clinoptilolite and those fed the control diet, with no clinoptilolite. Hens supplemented with $0.50 \%$ clinoptilolite presented the lowest calcium blood levels, whereas those fed $0.15 \%$, presented an intermediate concentration. Therefore, according to the results, dietary clinoptilolite supplementation effects were not beneficial to calcium blood levels, as birds not fed this zeolite presented statistically similar calcium blood levels as those supplemented with $0.25 \%$ de clinoptilolite; therefore, its use for this purpose is not viable.

Table 2 - Feed intake (FI) and blood uric acid and calcium concentrations of layer fed diets supplemented with clinoptilolite (CLINO) and containing different calcium levels (Ca).

\begin{tabular}{lccc}
\hline & $\begin{array}{c}\mathrm{Fl} \\
(\mathrm{g} / \mathrm{hen} / \text { day })\end{array}$ & $\begin{array}{c}\text { Calcium } \\
(\mathrm{mg} / \mathrm{dL})\end{array}$ & $\begin{array}{c}\text { Uric acid } \\
(\mathrm{mg} / \mathrm{dL})\end{array}$ \\
\hline CLINO (\%) & & & \\
\hline 0.00 & 117.83 & $16.67 \mathrm{~A}$ & 10.82 \\
0.15 & 118.63 & $15.72 \mathrm{~B}$ & 6.81 \\
0.25 & 117.98 & $16.73 \mathrm{~A}$ & 7.15 \\
0.50 & 119.32 & $10.87 \mathrm{C}$ & 10.91 \\
\hline Ca (\%) & & & \\
\hline 2.5 & 118.46 & 15.22 & 9.59 \\
3.1 & 119.50 & 14.88 & 9.32 \\
3.7 & 117.35 & 14.90 & 7.86 \\
\hline Mean & 118.44 & 15.00 & 8.92 \\
\hline CV (\%) & 4.08 & 7.08 & 34.02 \\
\hline P value & & & \\
\hline Clinoptilolite & 0.782 & 0.000 & 0.000 \\
Calcium & 0.310 & 0.466 & 0.112 \\
CLINO x CALCIUM & 0.135 & 0.991 & 0.000 \\
\hline
\end{tabular}

Means followed by different capital letters in the same column are statistically different by the test of Tukey $(p \leq 0.05)$

These results are consistent with the findings of Frost et al. (1992), who did not observe any beneficial effects of the dietary inclusion of zeolites $(0.75 \%)$ on total calcium blood concentrations of commercial layers. Roland et al. (1985) also did not find any influence of $0.0-1.5 \%$ zeolite dietary levels on calcium blood concentrations of layers. On the other hand, Leach Jr. et al. (1990) verified significant increase in broiler calcium blood levels with increasing dietary zeolite levels $(0.0,0.75$, and $1.5 \%)$.

Dietary calcium levels did not affect ( $p>0.05)$ calcium blood concentration. Based on feed intake, it was calculated that calcium intake ranged between $2.96 \mathrm{~g} / \mathrm{hen} /$ day for layers fed the lowest calcium level and $4.34 \mathrm{~g} / \mathrm{bird} /$ day for those fed the highest level. Pelícia et al. (2011), working with 3.0-4.5\% calcium levels in semi-heavy layer diets at the end of the first laying cycle, also did not observed any differences in calcium blood level, although calcium intake linearly 
increased with increasing dietary calcium content. Roland et al. (1985) also did not find any significant change in calcium blood concentrations in layers fed two different calcium levels (2.75 and $4.00 \%$ ). On the other hand, in second-cycle layers, blood calcium concentration linearly increased with dietary calcium levels, as well as calcium intake (Pelícia et al., 2009). In the present study, calcium intake numerically increased with dietary calcium levels, but blood calcium concentrations were not affected ( $p>0.05)$ by calcium intake.

The reported results are contradictory and may be attributed to differences in methodology, genetics and bird species, production periods, dietary calcium levels applied in the above-mentioned studies, which, according to Macari et al. (2002), may all affect calcium absorption rate. Calcium homeostatic mechanisms maintain extra-cellular calcium levels constant (Macari et al., 2002). In the present study, hens fed marginal calcium levels (2.5 and 3.1\%), corresponding to 2.96 and $3.70 \mathrm{~g}$ calcium intake/hen/day, respectively, presented constant calcium blood concentrations. The deficiency of this nutrient in the diet was probably compensated by calcium reabsorption in the kidneys and bone resorption.

Table 3 - Breakdown of the interaction between clinoptilolite and calcium levels relative to uric acid blood concentration.

\begin{tabular}{|c|c|c|c|c|}
\hline \multirow[t]{2}{*}{ Calcium (\%) } & \multicolumn{4}{|c|}{ Clinoptilolite (\%) } \\
\hline & 0.00 & 0.15 & 0.25 & 0.50 \\
\hline & \multicolumn{4}{|c|}{ Uric acid (mg/dL) } \\
\hline 2.5 & $18.54 a A$ & $6.09 b$ & $7.82 \mathrm{~b}$ & $5.90 \mathrm{bB}$ \\
\hline 3.1 & $7.77 \mathrm{bB}$ & $7.38 b$ & $4.85 b$ & 17.30aA \\
\hline 3.7 & $6.15 B$ & 6.96 & 8.79 & $9.53 B$ \\
\hline
\end{tabular}

Means followed by different capital letters in the same column and different small letters in the same row are statistically different by the test of Tukey $(p \leq 0.05)$

Table 3 shows that clinoptilolite levels influenced uric acid blood concentration when hens were fed 2.5 and $3.1 \%$ calcium. Those fed $2.5 \%$ calcium presented the lowest uric acid concentrations when combined with the zeolite, independently of level, whereas those fed $3.1 \%$ calcium had lower uric acid blood concentrations when no or $0.25 \%$ zeolite was fed. The diet containing $0.50 \%$ clinoptilolite and $3.1 \%$ calcium promoted the highest uric acid concentration. Uric acid blood concentration of layers fed $3.7 \%$ calcium was not influenced by dietary clinoptilolite level. Therefore, the results show that clinoptilolite was more effective when marginal calcium levels were fed, which was also found by Leach Jr. et al. (1990).
Blood uric acid concentrations of hens fed diets supplemented with $0.50 \%$ or no clinoptilolite were affected by dietary calcium levels. When hens received no clinoptilolite, blood uric acid concentration was significantly reduced with increasing dietary calcium level, decreasing from $18.54 \mathrm{mg} / \mathrm{dL}$ when hens were fed $2.5 \%$ calcium to $6.15 \mathrm{mg} / \mathrm{dL}$ when $3.7 \%$ calcium was offered. Birds fed $0.50 \%$ clinoptilolite presented the highest uric acid level when the diet contained $3.1 \%$ calcium.

Bone quality results are presented in Table 4.

There was no interaction ( $p>0.05)$ between clinoptilolite and calcium dietary levels, nor isolated effects of these factors on bone mineral density. This indicates that the dietary inclusion of clinoptilolite did not affect bone calcium resorption or deposition processes.

The lack of effect of dietary calcium levels on bone mineral density observed in the present study is consistent with the finding of Araújo et al. (2006), who also did not detect any differences in bone mineral density in the tibiae of broiler fed 0.8 or 0.8 e $0.6 \%$ calcium. On the other hand, Schreiweis et al. (2003) found a significant negative linear trend in bone mineral density when decreasing dietary calcium levels (5.4, 3.6, and 1.8\%). Almeida Paz et al. (2008) observed statistically lower bone mineral density of the tibiae of layers fed $1.8 \%$ calcium compared with $3.8 \%$.

There was no interaction $(p>0.05)$ between clinoptilolite and calcium dietary levels, nor isolated effects of clinoptilolite and calcium dietary levels on bone breaking strength or bone ash percentage. However, Leach Jr. et al. (1990), working with different synthetic zeolite $(0.0 ; 0.75$ e $1.5 \%)$ and calcium $(0.31$; $0.39 ; 0.47 ; 0.59$ e $1.01 \%$ ) levels in broiler diets, found that bone ash content increased when zeolite was added to low calcium diets, whereas it decreased broilers were fed zeolite and adequate calcium. The absence of influence of dietary calcium levels on bone breaking strength in the present experiment was also observed by Almeida Paz et al. (2008).

The obtained bone ash percentage results are not consistent with the findings of Leach Jr. et al. (1990), who reported higher bone calcification as dietary calcium increased.

The absence of effects of dietary clinoptilolite and calcium levels on bone quality parameters suggests that the hens' homeostatic mechanisms were able to maintain extracellular calcium levels constant without the need of mobilizing calcium from the bones. The bone 
Table 4 - Bone mineral density (BMD) of the proximal epiphysis (PE), diaphysis (DP), distal epiphysis (DE), and total bone density (TOTAL), breaking strength (BS), and ash percentage (ASH) of the tibiae of layers fed diets containing different clinoptilolite (CL) and calcium (Ca) levels.

\begin{tabular}{|c|c|c|c|c|c|c|}
\hline & \multicolumn{4}{|c|}{$\begin{array}{c}\text { BMD } \\
(\mathrm{mm} \mathrm{Al})\end{array}$} & \multirow[t]{2}{*}{$\begin{array}{c}\text { BS } \\
\text { (kgf) }\end{array}$} & \multirow[t]{2}{*}{$\begin{array}{l}\text { Ash } \\
(\%)\end{array}$} \\
\hline CLINO (\%) & PE & DP & DE & Total & & \\
\hline 0.00 & 3.39 & 2.37 & 3.31 & 9.07 & 7.32 & 53.84 \\
\hline 0.15 & 3.81 & 2.49 & 3.56 & 9.86 & 6.81 & 55.33 \\
\hline 0.25 & 3.44 & 2.36 & 3.14 & 8.94 & 6.56 & 55.01 \\
\hline 0.50 & 3.54 & 2.44 & 3.42 & 9.40 & 7.71 & 53.71 \\
\hline \multicolumn{7}{|l|}{$\mathrm{Ca}(\%)$} \\
\hline 2.5 & 3.40 & 2.28 & 3.44 & 9.12 & 7.16 & 55.11 \\
\hline 3.1 & 3.50 & 2.42 & 3.46 & 9.38 & 7.33 & 54.52 \\
\hline 3.7 & 3.73 & 2.54 & 3.17 & 9.44 & 6.81 & 53.78 \\
\hline Mean & 3.54 & 2.41 & 3.36 & 9.32 & 7.10 & 54.47 \\
\hline CV (\%) & 21.23 & 23.74 & 23.34 & 18.55 & 24.35 & 7.85 \\
\hline \multicolumn{7}{|l|}{$P$ value } \\
\hline CLINO & 0.348 & 0.906 & 0.431 & 0.398 & 0.195 & 0.578 \\
\hline Calcium & 0.311 & 0.281 & 0.366 & 0.786 & 0.569 & 0.562 \\
\hline CLINO X Ca & 0.060 & 0.336 & 0.334 & 0.150 & 0.462 & 0.516 \\
\hline
\end{tabular}

Means followed by different capital letters in the same column are statistically different by the test of Tukey $(p \leq 0.05)$

quality results reported in literature are contradictory and may be attributed to differences in methodology, genetics and bird species, production periods, zeolite sources and levels, dietary limestone solubility, dietary calcium levels evaluated, which, according to Macari et al. (2002), may all affect calcium absorption rate.

\section{CONCLUSIONS}

It was concluded that the inclusion of up to $0.50 \%$ clinoptilolite in layer diets does not affect blood uric acid and calcium concentrations or bone quality.

When layers at the end of the first laying cycle are fed ad libitum and present $119.50 \mathrm{~g} / \mathrm{hen} /$ day average feed intake, $3.1 \%$ dietary calcium promotes $3.7 \mathrm{~g} /$ hen/day calcium intake, which is sufficient to maintain calcium blood levels and bone quality.

\section{REFERENCES}

Albano Júnior M, Albuquerque R, Lima CG, Ghion E, Lima FR, Morais CSD. Desempenho e qualidade dos ovos de diferentes linhagens de poedeiras comerciais pós-muda forçada recebendo rações com níveis variáveis de cálcio. Brazilian Journal Veterinary Research Aniamal Science 2000;37(4).

Almeida Paz ICL, Mendes AA, Balog A, Komiyama CM, Takahashi SE, Almeida ICL, Garcia EA, Vulcano LC, Ballarin AW, Martins MRFB, Bueno LGF. Qualidade óssea, produção e qualidade de ovos de poedeiras semi-pesadas em primeiro ciclo de produção. Pubvet 2008;2(23):248.

Araújo CSS, Artoni SMB, Araújo LF, Junqueira OM, Louzada MJQ, Oliveira D. Densidade óssea de frangos de corte alimentados com diferentes níveis de aminoácidos e cálcio durante a fase final de criação. Acta Scientarium Animal Science 2006;28(2):203-208.
Armbruster T. Clinoptilolite-heulandite: applications and basic research. Zeolites and Mesoporous Material at the Dawn 2001;21:127-135.

Bronner F. Intestinal calcium absorption: mecanisms and applications. Journal Nutrition 1987;117:1347-1352.

Ferreira DP. Programa Sisvar.exe. Sistema de Análises de Variância. Versão 3.04. Lavras: UFLA; 1998

Frost TJ, Roland SR DA, Barnes DG, Laurent SM. The effect of sodium and cholecalciferol on plasma levels oh 1.25 dihydroxycholecalciferol, calcium, and phosphorus in commercial leghorns. Poultry Science 1992;71:886-893

Highfill C. Calcium, phosphorus and vitamin D3 in your birds dieta. Winged Wiston Pet Bird Magazine. April Magazine; 1998.

Junqueira OM, Rodrigues EA. Balanço de cálcio e fósforo em poedeiras comerciais. In: Berchieri Júnior A. Atualização em avicultura para poedeiras comerciais. Jaboticabal (SP): FUNEP; 2004.

Keshavarz K. The effect of dietary levels of calcium and phosphorus on performance and retention of these nutrientes by layng hens. Poultry Science 1986;65(1):114-121.

Klasing KC. Comparative avian nutrition. Wallingford (UK): CABI Publishing; 1998.

Larbier M, Leclerq B. Nutrition and feeding of poultry. Nottingham: University Press; 1992.

Leach Júnior RM, Heinrichs BS, Burdette J. Broiler chicks fed low calcium diets. 1: influence of zeolite on growth rate and parameters of bone metabolism. Poultry Science 1990;69:1535-1539.

Louzada MJQ. Otimização da técnica de densitometria óptica em imagens radiográficas de peças ósseas: estudos "in vitro" [tese]. Campinas (SP): Universidade Estadual de Campinas; 1994.

Luz AB. Zeólitas: propriedades e usos industriais [tecnologia mineral 68] Rio de Janeiro: Cetem; 1995.

Macari M, Furlan RL, Gonzales E. Fisiologia aviária aplicada a frangos de corte. Jaboticabal (SP): FUNEP, UNESP; 2002. 
Mumpton FA. La roca majica: uses of natural zeolites in agriculture and industry. National Academy of Science of the USA 1999;96:34633470

Nakaue HS, Koelliker JK. Studies with clinoptilolite in poutltry. I. effect of feeding varying levels of clinoptilolite (zeolite) to dwarf single comb with leghorn pullets and ammonia production. Poultry Science $1981 ; 60: 944-949$

Nogueira ARA, Souza GB. Manual de laboratório: solo, água, nutrição vegetal, nutrição animal e alimentos. São Carlos: Embrapa Pecuária Sudeste; 2005.

Pelícia K, Mourão JLM, Garcia EA, Pinheiro VMC, Berto DA, Molino AB, Faitarone, ABG, Vercese F, Santos GC, Silva AP. Effects of dietary calcium levels and limestone particicle size on the performance, tibia and blood of laying hens. Brazilian Journal of Poultry Science $2011 ; 13(1): 29-34$

Pelicia K, Garcia EA, Faitarone ABG, Silva AP, Berto DA, Molino AB, Vercese F. Calcium and available phosphorus levels for laying hens in second production cycle. Brazilian Journal of Poultry Science 2009;11(1):39-49.

Perkin-Eimer Corporation. Anatomic absortion spectroscopy analytical methods. Norwalk; 1996.

Pizauro Júnior JM. Hormônios e regulação do tecido ósseo. In: Macari M, Furlan RL, Gonzales E. Fisiologia aviária aplicada a frangos de corte. Jaboticabal (SP): FUNEP; 2002.

Rabon HW, Roland SR DA, Bryant M, Barnes DG, Laurent SM. Influence of sodium zeolite A with and without pullet-sozed limestone or oyster shell on eggshell quality. Poultry Science 1991;70:1943-1947.

Roland SR DA, Barnes DG, Laurent SM. Influence of sodium aluminosilicate, hydroxyl-sodalite, carnegicite, aluminium sulfate and aluminium phosphate on performance of commercial leghorns. Poultry Science $1991 ; 70: 805-811$

Roland SR DA. Further studies of effect of phosphorus and aluminosilicate on egg shell quality. Poultry Science 1988;67:577-584.

Roland SR DA, Laurent SM, Orloff HD. Shell qality is influenced by zeolite with high ion-exchange capability. Poultry Science 1985;64:11771187.

Rostagno HS, Albino LFT, Donzele JL, Gomes PC, Oliveira RF, Lopes DC, Ferreira AS, Barreto SLT. Tabelas brasileiras para aves e suínos: composição de alimentos e exigências nutricionais. $2^{\text {a }}$ ed. Viçosa (MG): UFV; 2005.

Santurio JM, Mallmann CA, Rosa AP, Appel G, Heer A, Dageforde S, Bottcher M. Effect of sodium bentonite on the performance an bood variables of broiler chickens in intoxicated with aflatoxin. British Poultry Science 1999:40:115-119.

Schreiweis MA, Orban Jl, Ledur MC, Hester PY. The use densitometry to detect differences in bone mineral density and content of live white Leghorns fed varying levels of dietary calcium. Poultry Science 2003;82:1292-1301.

Shariatmadari F. The aplication of zeolite in poultry production. World's Poultry Science Journal 2008;64:76-84

Shurson GC, Ku PK, Miller ER, Yokoyama MT. Effects of zeolite A or clinoptilolite in diets of growing swine. Journal Animal Science 1984;59(6):1536-1545.

Underwood EJU. The mineral nutrition of livestock. $2^{\text {nd }}$ ed. London: Commonwealth Agricultural Bureau; 1981.

Zigger D. Study affirm microbe resistance. World Poultry 1998;14(9) 